\title{
A STUDY OF "TITLE" FUNCTION IN TRANSFERRING AND TURNING OF CONCEPT IN VISUAL CONCEPTUAL ART
}

\author{
Behrouz Soheili ESFAHANI \\ Master of Art and Research student, Faculty of Art, Shahed University, Tehran, Iran \\ Behrouz.soheili.esfahani@gmail.com \\ Mohsen MARASY \\ Assistant Professor, Faculty of Art, Shahed University, Tehran, Iran \\ marasy@shahed.ac.ir
}

\begin{abstract}
By paying more attention to "concept" of artwork in Postmodern and Contemporary Art, and with the advent of Hermeneutic and Intertextual topics in art, attentions to "title" effects on transferring and turning of concept have increased. Conceptual Art has concerned with these effects more than the other movements. The purpose of this study is identifying of "title" function in visual conceptual art and "title" effectiveness on audience's perception of these works. The article has been conducted on the basis of a Sequential Multi-Method including Semi-Experimental, and Content Analysis methods. The researchers have been experimented "title" effects by semi-experimental method on perception of the sample group members of two visual conceptual artworks. Each one of these two works which made by the researcher have been presented to respondents in "without title" and "titled" situations in which has been requested them to write their perception of the artworks by separate questionnaires including an open-ended question. Then, the information has been processed using content analysis method. The results have been analyzed quantitatively and qualitatively. The authors have based Set Theory in quantitative study part. this article has innovation not only in applying combined methodology in art territory studies, but also in studying "title" effects quantitatively. The results show that "title" in a visual conceptual artwork is considered the part of a work itself and it's not something separate from it. Furthermore, "title" involves in transferring visual conceptual artworks concept and can change their concept between $70 \%$ to $80 \%$ and turn it between $50 \%$ to $64 \%$ and concentrate it into some concepts that itself predicate on them, but cannot thin it out into one. "Title" is also able to limit audience's perception of these works between $47 \%$ to $61 \%$ and expand it between $19 \%$ to $32 \%$ and create new concepts.
\end{abstract}

Keywords: Title, Visual Conceptual Art, Concept of Artwork, Audience's Perception of Artwork, Entitling

\section{INTRODUCTION}

Some believe that the "title" of a artwork affects the audience reading and is considered as a dishonor to him. Some also think that a work of art in itself is obvious and does not require attaching words or phrases such as labels to it in order to add an explanation. But some also suggest that titles play a serious role in understanding and perception of the audience, and is a measure that the work creator uses it to convey intended meaning to the audience. In the post-modern and contemporary art, with further consideration of meaning and hidden concept in the artwork and addressing Hermeneutics and Intertextuality topics in visual art, given the role of the "title" is increased in the transfer of the concept so, artists by titling their works consciously, try to determine the overall direction of their work. In the meantime, conceptual art, more than any other current trends, has paid attention to "title" because in this kind of art the idea and concept play an essential role. In the late 60 s, increasing growth of texts on art galleries disturbed the distinction between exhibition and publication spaces, conceptual paintings were concern to represent the meaning and as much as artists used to emphasize visual forms, also overemphasized semantic content of words painted. "Language" in the sense of unlimited and fresh artistic material became a very important tool (Osborne, 2012: 32-42 and Lucie-Smith, 2008: 
201-205). The majority of visual works of conceptual art either had a "title" or that the visual "text" was to a part of the work and plays a role in the transition of the concept. How to transfer this concept to the audience is a topic that has been studied in this research and the difference in understanding and perception of the audience of a conceptual visual work is tested in the presence and absence of the "title" to determine the importance of the title in this art type. Accordingly, in the present study the authors attempt to test the "title" function in two conceptual visual works (created by one of them) and evaluate its effect on the audience's perception of the work to determine the role of the title in a conceptual art work in the transfer and turning of the concept.

Although traditional classifications of art into contemporary and conceptual art are considered as rejected, but in this study, there is an assumed border among works of conceptual art in order to limit research area. So that introduced works based on traditional media of art (e.g., painting, sculpture and photography) have been considered in the form of groups named "visual conceptual art works" and have been distinguished from others in order to examine the "title" function in these works.

\section{LITERATURE REVIEW}

A literature search that was conducted in computerized bibliographic databases about "title" effects on audience's perception of artwork shows a few studies which none of them have focused on conceptual art and none of them have addressed quantitative effects of "title". These studies are:

\section{- The Influence of Titles on How Paintings Are Seen:}

This paper states that changing the "title" causes interpretive readings of a painting and when an artwork is titled will represent a significant effect on its aesthetics and the quality that we understand. The attempt to achieve a balance between the "title" and visual image is considered as a part of the viewer experience and different species of the title uses and directs the viewer in different ways (Franklin, Becklen, and Doyle, 1993).

\section{- Entitling Art: Influence of Title Information on Understanding and Appreciation of Paintings:}

This paper states that it seems that if there is enough time to perceive the meaning by the audience, understand the work of art becomes important (Ledera, Carbona and Ripsasb, 2006).

\section{- A Study of Title Role in Expressive Functions of photos}

Results of this thesis state that in the transfer of the meaning of a titled picture, the "title" can play a role as an identifier, creator and sometimes changer of the meaning and its message is received at different levels to achieve the ultimate meaning of a work. Hence, ignoring the title role in reading a titled picture content is as removing a part of the picture (Abdollahabadi and Moghimnejad, 2012).

- Title Paratextualite and Titling as a Threshold of Text in Cinema with an Emphasis on Abbas Kiarostami's films

This thesis relying on Gérard Genette theories of Intertextuality, states that the "title" and "titling" of a film have been introduced as a kind of text that plays a role in the audience reading of the text of an artwork (Moadikhah and Namvar Motlaq, 2013).

\section{METHODOLOGY}

This study is conducted based on a sequential multi method (Creswell, John W., 2013), including methods of semi-experimental and descriptive content analysis at two stages. Thus, at the first stage, the researchers using semi-experimental method have tested the independent variable (title) in the sample and at the second stage, using descriptive content analysis have processed data obtained from semi-experimental part (answers to open questionnaires) as the raw data and then using multi method (quantitative and qualitative) have analyzed them. Since the method of collecting data in this research is multi method (both library and fieldwork), in the library part, taking notes and in the field part, researcher-made written questionnaire with only one question has been used. The reason for using this type of questionnaire is to minimize the effect of other factors on the mind and perception of the sample members (other than the "title" as the independent variable). The authors have considered the 
population as students and graduates of undergraduate and postgraduate available. Sampling method is "non- probability purposive" and the sample size has been selected 15 persons. Because it was attempted to select a diverse range of persons to establish age, gender, education diversity and the results are not biased to a particular group. Thus, the sample composed of 7 men and 8 women, ages 20 to 50 years, in academic disciplines of arts, humanities, medical and experimental sciences, 6 persons with undergraduate education, 6 persons had MS and 3 persons had Ph.D. degree. Each person was asked to write his perception of "Work 1" and "Work 2" given in " Image 1 and 2," once in the absence of the "title", and once for the first title and last time for the second title.

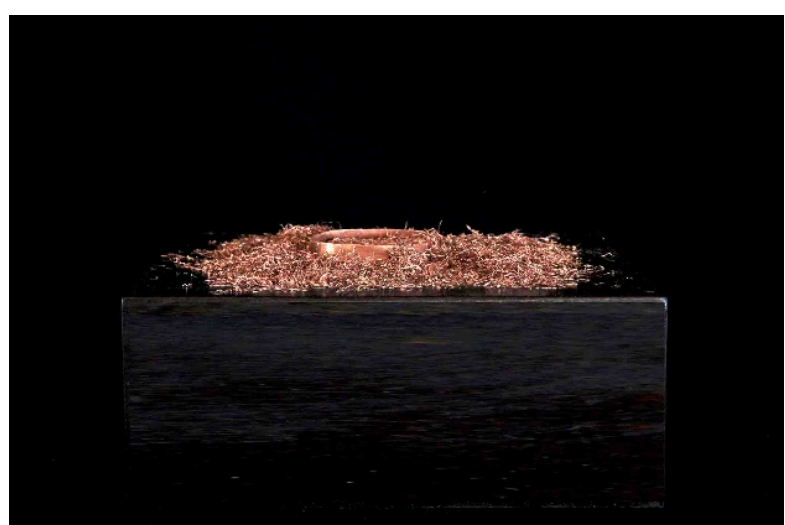

Image 1. Work 1, the author work, shaped copper piece and copper filings on wooden base, $22 * 20 * 12 \mathrm{~cm}$, source: Authors

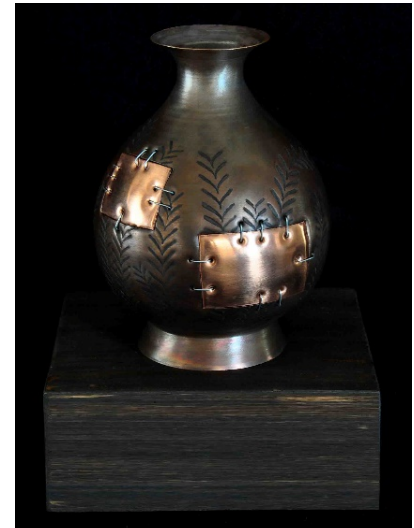

Image 2. Work 2, the author work, copper vase and iron wire on wooden base, $16 * 18 * 28 \mathrm{~cm}$, source: Authors

\section{Semi-experimental stage}

Thus, at the first stage, "Work 1" without any title is provided to the sample population. In a question in the questionnaire they were asked to write their perception to the work at least in 5 lines. At the second stage, title of "Love Elixir Fell on My Copper and ..." ${ }^{(1)}$ was put under the work they were asked to write their perception to the work according to the title at least in 5 lines. At the third stage, the previous title of the work was removed and the second title i.e. "Nothingness" was placed below it and members were asked to write their perception to the work according to the title at least in 5 lines. At the end of these three stages, a total of 45 questionnaires of the audience's perception of "Work 1" were collected. This trend was done for "Work 2" but with the difference that its titles are "Modernity" and "Looking for Authenticity Preservation". A total of 6 stages, 90 questionnaires entered the next stage of the research that would be content analysis.

\section{CONTENT ANALYSIS STAGE}

Research at the second stage used category content analysis and, subsequently, to extract the concepts contained in the questionnaire. For this purpose, the authors have encoded the questionnaires' text sentence by sentence. This means that apparent concept of each sentence implies has been extracted without interpretation and recorded in the form of a code. At the first stage, in coding "Work 1", 252 codes were counted, but at next stages, codes with similar content and close together were integrated, so that at the second stage of coding, the codes were reduced to 22 ones and at the third stage were reduced to 17 ones. During coding process of resulting questionnaires of "Work 2" also encoded at the first stage, 235 codes were counted and at the second and third stages codes were reduced to 16 and 13 codes, respectively. According to the results of the questionnaires' rewriting based on the third layer codes for each "Works (1) and (2)", "Separate Tables 1 and 2" have been drawn indicating that each person had referred to what concepts at each of the three stages about each work and how the concept dispersion has been.

Table 1. Perceived concepts' distribution by respondents of "Work 1" as without title (a), the first*(b) and second ${ }^{* *}$ (c) titles 
The Turkish Online Journal of Design, Art and Communication - TOJDAC January 2017 Volume 7 Issue 1

\begin{tabular}{|c|c|c|c|c|c|c|c|c|c|c|c|c|c|c|c|c|c|c|}
\hline 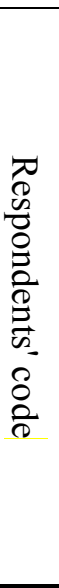 & 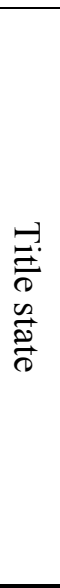 & 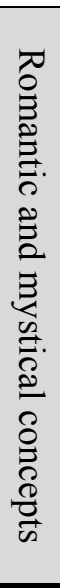 & 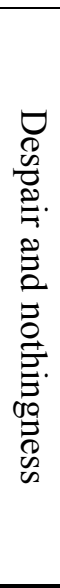 & 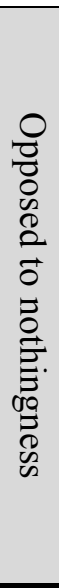 & 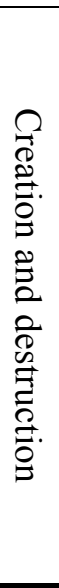 & 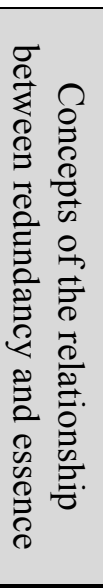 & 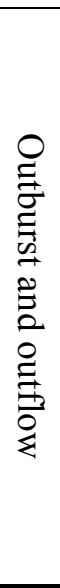 & 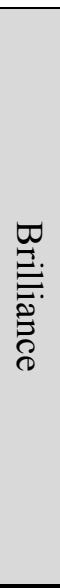 & 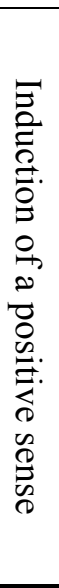 & 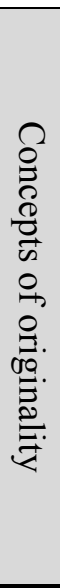 & 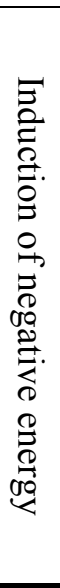 & 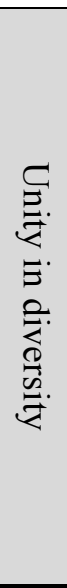 & 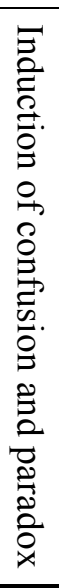 & 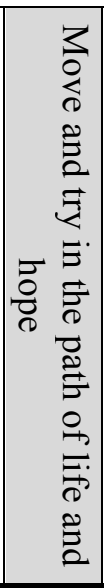 & 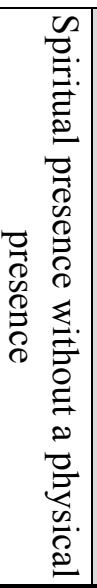 & 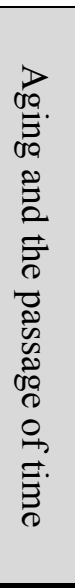 & 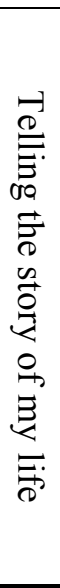 & $\begin{array}{l}\stackrel{-}{\overrightarrow{0}} \\
\stackrel{\circ}{\circ} \\
\stackrel{\vec{े}}{\oplus}\end{array}$ \\
\hline \multirow{3}{*}{01} & $\mathrm{a}$ & & $\checkmark$ & & $\checkmark$ & & $\checkmark$ & & & & $\checkmark$ & & & & & $\checkmark$ & & $\checkmark$ \\
\hline & $\mathrm{b}$ & $\checkmark$ & $\checkmark$ & & & & & & & & & & & & & & & \\
\hline & $\mathrm{c}$ & & $\checkmark$ & & & & & & & & & & & & & $\checkmark$ & & \\
\hline \multirow{3}{*}{02} & $\mathrm{a}$ & $\checkmark$ & & & & $\checkmark$ & & $\checkmark$ & $\checkmark$ & & & & & & & & $\checkmark$ & \\
\hline & $\mathrm{b}$ & $\checkmark$ & & & & $\checkmark$ & & & & & & & $\checkmark$ & & & & $\checkmark$ & \\
\hline & $\mathrm{c}$ & $\checkmark$ & $\checkmark$ & $\checkmark$ & & $\checkmark$ & & & & & & & & & & & & \\
\hline \multirow{3}{*}{03} & $\mathrm{a}$ & $\checkmark$ & & & $\checkmark$ & & & & & & & & $\checkmark$ & & & & & $\checkmark$ \\
\hline & $\mathrm{b}$ & $\checkmark$ & & & $\checkmark$ & & & & & & & & & & & & & \\
\hline & $\mathrm{c}$ & $\checkmark$ & & $\checkmark$ & $\checkmark$ & & & & & $\checkmark$ & & & & & & & & \\
\hline \multirow{3}{*}{04} & $\mathrm{a}$ & & $\checkmark$ & & & & & & & $\checkmark$ & $\checkmark$ & & $\checkmark$ & & & & & $\checkmark$ \\
\hline & $\mathrm{b}$ & $\checkmark$ & $\checkmark$ & & & & & & $\checkmark$ & & & & & & $\checkmark$ & & & $\checkmark$ \\
\hline & $\mathrm{c}$ & $\checkmark$ & $\checkmark$ & $\checkmark$ & & & & & $\checkmark$ & $\checkmark$ & & & & $\checkmark$ & & & $\checkmark$ & \\
\hline \multirow{3}{*}{05} & $\mathrm{a}$ & $\checkmark$ & $\checkmark$ & & & & & & $\checkmark$ & & & $\checkmark$ & $\checkmark$ & $\checkmark$ & & & & \\
\hline & $\mathrm{b}$ & $\checkmark$ & & & & & & & & & & & & $\checkmark$ & & & & $\checkmark$ \\
\hline & $\mathrm{c}$ & & $\checkmark$ & $\checkmark$ & & & & & & & & & $\checkmark$ & & & & & \\
\hline \multirow{3}{*}{06} & $\mathrm{a}$ & & $\checkmark$ & & $\checkmark$ & & $\checkmark$ & & & $\checkmark$ & & & & & $\checkmark$ & & & \\
\hline & $\mathrm{b}$ & $\checkmark$ & & & & & & & $\checkmark$ & & & & & & & & & \\
\hline & $\mathrm{c}$ & $\checkmark$ & $\checkmark$ & & & & & & & & $\checkmark$ & & & & & & & \\
\hline \multirow{3}{*}{07} & $\mathrm{a}$ & & & & & & $\checkmark$ & $\checkmark$ & & & & $\checkmark$ & & & & $\checkmark$ & & \\
\hline & $\mathrm{b}$ & $\checkmark$ & & & & & & & & & & $\checkmark$ & & & & & & \\
\hline & $\mathrm{c}$ & $\checkmark$ & & $\checkmark$ & & & & & & & & & & & & & & \\
\hline \multirow{3}{*}{08} & $\mathrm{a}$ & $\checkmark$ & & & & & & & & & & $\checkmark$ & & & & & & \\
\hline & $\mathrm{b}$ & $\checkmark$ & & & & & & & & & & & & & & & & \\
\hline & $\mathrm{c}$ & $\checkmark$ & & & & & & & & & & & & & & & & \\
\hline \multirow{3}{*}{09} & $\mathrm{a}$ & $\checkmark$ & $\checkmark$ & & & & & & & $\checkmark$ & & & & & & $\checkmark$ & & \\
\hline & $\mathrm{b}$ & $\checkmark$ & & & & & & & & & & & & & & & & \\
\hline & $\mathrm{c}$ & & & $\checkmark$ & & & & & & & & & & & & & & \\
\hline \multirow{3}{*}{10} & $\mathrm{a}$ & & & & & & & $\checkmark$ & & $\checkmark$ & & & & & & $\checkmark$ & & $\checkmark$ \\
\hline & $\mathrm{b}$ & $\checkmark$ & & & & & & & & & & & & & & & & \\
\hline & $\mathrm{c}$ & & $\checkmark$ & & & & & & & & & & & & & & & $\checkmark$ \\
\hline \multirow{3}{*}{11} & $\mathrm{a}$ & & & & & & $\checkmark$ & & & & & & & & & & & \\
\hline & $\mathrm{b}$ & $\checkmark$ & & & & & & & & & & & & & & & & \\
\hline & $\mathrm{c}$ & & & $\checkmark$ & & & & & & & & & & & & & & \\
\hline \multirow{3}{*}{12} & $\mathrm{a}$ & & & & $\checkmark$ & $\checkmark$ & & & & & & & & & & & & \\
\hline & $\mathrm{b}$ & $\checkmark$ & & & & & & & & & & & & & & & & \\
\hline & $\mathrm{c}$ & & $\checkmark$ & & & & & & & & & & & & & & & \\
\hline \multirow{3}{*}{13} & $\mathrm{a}$ & $\checkmark$ & $\checkmark$ & & $\checkmark$ & & & & & & & & & $\checkmark$ & & & $\checkmark$ & \\
\hline & $\mathrm{b}$ & $\checkmark$ & & & & & & & & & & & & & & & & $\checkmark$ \\
\hline & $\mathrm{c}$ & & $\checkmark$ & & & & & & & & & & & & & & & \\
\hline
\end{tabular}


The Turkish Online Journal of Design, Art and Communication - TOJDAC January 2017 Volume 7 Issue 1

\begin{tabular}{|c|c|c|c|c|c|c|c|c|c|c|c|c|c|c|c|c|c|c}
\hline \multirow{5}{*}{14} & $\mathrm{a}$ & & $\checkmark$ & & $\checkmark$ & & & & & & & & & & & $\checkmark$ & & \\
\hline & $\mathrm{b}$ & $\checkmark$ & & & & & & & & & & & & & & & & \\
\hline & $\mathrm{c}$ & & $\checkmark$ & & & & & & & & & & & $\checkmark$ & & & & $\checkmark$ \\
\hline \multirow{3}{*}{$\mathbf{1 5}$} & $\mathrm{a}$ & & $\checkmark$ & & & & $\checkmark$ & & & & & & & $\checkmark$ & & & & \\
\hline & $\mathrm{b}$ & $\checkmark$ & & & & & & & & & & & & & & & & \\
\hline & $\mathrm{c}$ & & $\checkmark$ & & & & & & & & & & & & & & & \\
\hline
\end{tabular}

* and **: The first and second titles, respectively are states of the work titled "Love Elixir Fell on My

Copper and ..." and "Nothingness" provided to respondents.

Table 2. Perceived concepts' distribution by respondents of "Work 2 " as without title (a), the first* (b)

\begin{tabular}{|c|c|c|c|c|c|c|c|c|c|c|c|c|c|c|}
\hline $\begin{array}{l}7 \\
0 \\
0 \\
0 \\
0 \\
0 \\
0 \\
0 \\
\stackrel{0}{0} \\
\stackrel{0}{0} \\
0 \\
\delta \\
0 \\
0\end{array}$ & 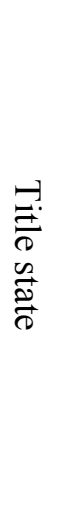 & 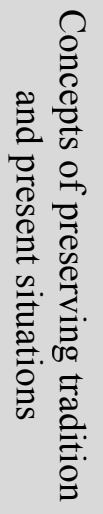 & 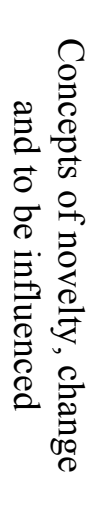 & 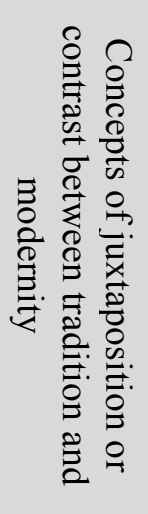 & 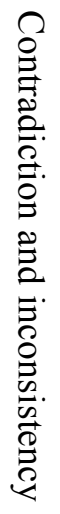 & 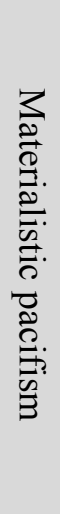 & 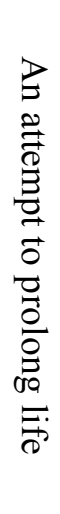 & 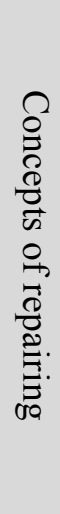 & 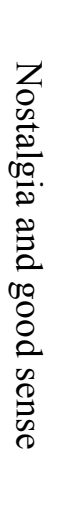 & 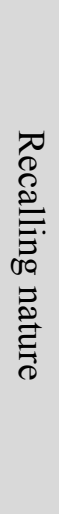 & 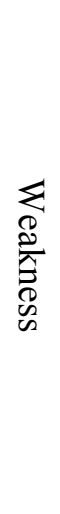 & 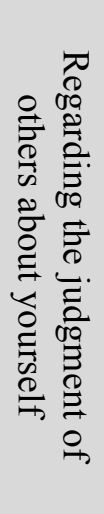 & 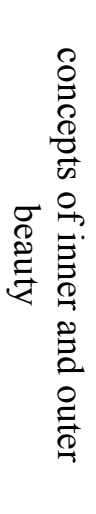 & 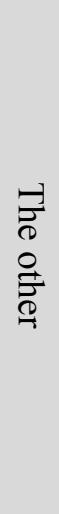 \\
\hline \multirow{3}{*}{01} & $\mathrm{a}$ & $\checkmark$ & $\bar{\checkmark}$ & & & & & $\checkmark$ & $\checkmark$ & & & & & \\
\hline & $\mathrm{b}$ & & & $\checkmark$ & $\checkmark$ & & & & & & & & & \\
\hline & $\mathrm{c}$ & $\checkmark$ & & & & & & & $\checkmark$ & & & & & \\
\hline \multirow{3}{*}{02} & $\mathrm{a}$ & & & & $\checkmark$ & & & $\checkmark$ & $\checkmark$ & & & & & \\
\hline & $\mathrm{b}$ & & $\checkmark$ & $\checkmark$ & $\checkmark$ & & & & & & & & & $\checkmark$ \\
\hline & $\mathrm{c}$ & $\checkmark$ & $\checkmark$ & & $\checkmark$ & & & & & & & & & $\checkmark$ \\
\hline \multirow{3}{*}{03} & $\mathrm{a}$ & & $\checkmark$ & & $\checkmark$ & & & $\checkmark$ & & & & & & \\
\hline & $\mathrm{b}$ & $\checkmark$ & & & & & & & & & & & & $\checkmark$ \\
\hline & $\mathrm{c}$ & $\checkmark$ & $\checkmark$ & & & & & & & & & & & \\
\hline \multirow{3}{*}{04} & $\mathrm{a}$ & $\checkmark$ & & $\checkmark$ & $\checkmark$ & & & & $\checkmark$ & $\checkmark$ & & & & \\
\hline & $\mathrm{b}$ & & $\checkmark$ & $\checkmark$ & & & & & & & & & & \\
\hline & $\mathrm{c}$ & $\checkmark$ & & & & & & & & $\checkmark$ & & & & $\checkmark$ \\
\hline \multirow{3}{*}{05} & $\mathrm{a}$ & & $\checkmark$ & & $\checkmark$ & & $\checkmark$ & & & & $\checkmark$ & & & \\
\hline & $\mathrm{b}$ & & $\checkmark$ & & & & & & & & & & & $\checkmark$ \\
\hline & c & $\checkmark$ & & & & & & & & & & & & $\checkmark$ \\
\hline \multirow{3}{*}{06} & $\mathrm{a}$ & & & $\checkmark$ & $\checkmark$ & $\checkmark$ & & & & & & & & \\
\hline & $\mathrm{b}$ & & & $\checkmark$ & & & & & & & & & & $\checkmark$ \\
\hline & $\mathrm{c}$ & $\checkmark$ & & & & & & $\checkmark$ & & & & & & \\
\hline \multirow{3}{*}{07} & $\mathrm{a}$ & & & & & & & $\checkmark$ & & & & & & $\checkmark$ \\
\hline & $\mathrm{b}$ & & & $\checkmark$ & & & & & & & & & & \\
\hline & $\mathrm{c}$ & $\checkmark$ & & & & & & $\checkmark$ & & & & & & \\
\hline \multirow{3}{*}{08} & $\mathrm{a}$ & & & & $\checkmark$ & & & & & & & & & \\
\hline & $\mathrm{b}$ & & $\checkmark$ & & $\checkmark$ & & & & & & & & & \\
\hline & $\mathrm{c}$ & $\checkmark$ & & & $\checkmark$ & & & & & & & & & \\
\hline \multirow{3}{*}{09} & $\mathrm{a}$ & $\checkmark$ & & & $\checkmark$ & $\checkmark$ & & & & & & & & \\
\hline & $\mathrm{b}$ & $\checkmark$ & $\checkmark$ & & & & & & & & & & & \\
\hline & c & $\checkmark$ & $\checkmark$ & & & & & & & & & & & \\
\hline 10 & $\mathrm{a}$ & $\checkmark$ & & $\checkmark$ & $\checkmark$ & & & $\checkmark$ & & $\checkmark$ & & & & $\checkmark$ \\
\hline
\end{tabular}




\begin{tabular}{|c|c|c|c|c|c|c|c|c|c|c|c|c|c|}
\hline & $\mathrm{b}$ & & $\checkmark$ & $\checkmark$ & $\checkmark$ & & & & & & & & \\
\hline & $\mathrm{c}$ & & & $\checkmark$ & $\checkmark$ & & & & & $\checkmark$ & & & $\checkmark$ \\
\hline \multirow{3}{*}{11} & $\mathrm{a}$ & & & & & & & & & & & $\checkmark$ & \\
\hline & $\mathrm{b}$ & $\checkmark$ & $\checkmark$ & & & & & & & & & & \\
\hline & $\mathrm{c}$ & $\checkmark$ & $\checkmark$ & & & & & & & & & & \\
\hline \multirow{3}{*}{12} & $\mathrm{a}$ & & & & $\checkmark$ & $\checkmark$ & $\checkmark$ & & & & & & \\
\hline & $\mathrm{b}$ & & & & & $\checkmark$ & $\checkmark$ & & & & & & \\
\hline & $\mathrm{c}$ & $\checkmark$ & & & & & $\checkmark$ & & & & & & \\
\hline \multirow{3}{*}{13} & $\mathrm{a}$ & & & & $\checkmark$ & $\checkmark$ & $\bar{\checkmark}$ & & $\checkmark$ & & & & \\
\hline & $\mathrm{b}$ & & $\checkmark$ & & & $\checkmark$ & & & & & $\checkmark$ & & \\
\hline & $\mathrm{c}$ & $\checkmark$ & & & & $\checkmark$ & & & & & & & \\
\hline \multirow{3}{*}{14} & $\mathrm{a}$ & & $\checkmark$ & & & $\checkmark$ & $\checkmark$ & $\checkmark$ & & & & & \\
\hline & $\mathrm{b}$ & & $\checkmark$ & & & & & & & & & & \\
\hline & $\mathrm{c}$ & $\checkmark$ & & & & & & & & & $\checkmark$ & & \\
\hline \multirow{3}{*}{15} & $\mathrm{a}$ & & & & & & $\checkmark$ & $\checkmark$ & & & & & \\
\hline & $\mathrm{b}$ & & $\checkmark$ & & & $\checkmark$ & & & & & & & \\
\hline & $\mathrm{c}$ & $\checkmark$ & & & & & & & & & & & \\
\hline
\end{tabular}

* and **: The first and second titles, respectively are states of the work titled "Modernity" and "Looking for Authenticity Preservation" provided to respondents.

Data from the "Tables 1 and 2" should change into quantitative data to calculate the effect of the title on the audience understanding of conceptual visual work. To convert these data extracted from content analysis method to analyzed data in quantitative method, "Set Theory" (Stewart and T, 1986: 45-65 and Jamali, 2004: 1-7) has been used, so that based on the data of "Tables 1 and 2", for each person for each of the two conceptual works, three separate sets were defined which members are concepts that the person has mentioned:

Set A: Concepts referred to by one member of the sample population without any "title" for "Work 1" Set B: Concepts referred to by the person with the $1^{\text {st }}$ "title" for "Work 1"

Set C: Concepts referred to by the person with the $2^{\text {nd }}$ "title" for "Work 1"

The sets have been provided and described with the help of "formula 1-10" in "Table 3", indicating features that authors seek to measure them.

Table 3. Used formula in this study according to "Set Theory"

\begin{tabular}{|c|c|c|c}
\hline No. & Formula & Formula description & $\begin{array}{c}\text { Formula description on the "title" effect } \\
\text { on "respondent's perception" }\end{array}$ \\
\hline 1 & $\frac{A-B}{A \cup B} \times 100$ & $\begin{array}{c}\text { Percentage amount of } \\
\text { limitation of Set } \mathrm{B} \text { to Set A }\end{array}$ & $\begin{array}{c}\text { Amount of limitation of a person's } \\
\text { perception in the first title state to without } \\
\text { title state }\end{array}$ \\
\hline 2 & $\frac{B-A}{A \cup B} \times 100$ & $\begin{array}{c}\text { Percentage amount of } \\
\text { expansion of Set B to Set A }\end{array}$ & $\begin{array}{c}\text { Amount of expansion of a person's } \\
\text { perception in the first title state to without } \\
\text { title state }\end{array}$ \\
\hline 3 & $\frac{A \cap B}{A \cup B} \times 100$ & $\begin{array}{c}\text { Percentage amount of } \\
\text { Intersection of Set B to Set A }\end{array}$ & $\begin{array}{c}\text { Amount of unity of a person's perception in } \\
\text { the first title state to without title state }\end{array}$ \\
\hline 4 & $\frac{A \Delta B}{A \cup B} \times 100$ & $\begin{array}{c}\text { Percentage amount of } \\
\text { changes of Set B to Set A }\end{array}$ & $\begin{array}{c}\text { Amount of changes of a person's perception } \\
\text { in the first title state to without title state }\end{array}$ \\
\hline 5 & $\frac{A-C}{A \cup C} \times 100$ & $\begin{array}{c}\text { Percentage amount of } \\
\text { limitation of Set } \mathrm{C} \text { to Set A }\end{array}$ & $\begin{array}{c}\text { Amount of limitation of a person's } \\
\text { perception in the second title state to without } \\
\text { title state }\end{array}$ \\
\hline 6 & $\frac{C-A}{A \cup C} \times 100$ & $\begin{array}{c}\text { Percentage amount of } \\
\text { expansion of Set } \mathrm{C} \text { to Set A }\end{array}$ & $\begin{array}{c}\text { Amount of expansion of a person's } \\
\text { perception in the second title state to without } \\
\text { title state }\end{array}$ \\
\hline
\end{tabular}


The Turkish Online Journal of Design, Art and Communication - TOJDAC January 2017 Volume 7 Issue 1

\begin{tabular}{|c|l|c|c}
\hline 7 & $\frac{A \cap C}{A \cup C} \times 100$ & $\begin{array}{c}\text { Percentage amount of } \\
\text { Intersection of Set } \mathrm{C} \text { to Set } \mathrm{A}\end{array}$ & $\begin{array}{c}\text { Amount of unity of a person's perception in } \\
\text { the second title state to without title state }\end{array}$ \\
\hline 8 & $\frac{A \Delta C}{A \cup C} \times 100$ & $\begin{array}{c}\text { Percentage amount of } \\
\text { changes of Set } \mathrm{C} \text { to Set } \mathrm{A}\end{array}$ & $\begin{array}{c}\text { Amount of changes of a person's perception } \\
\text { in the second title state to without title state }\end{array}$ \\
\hline 9 & $\frac{B \cap C}{B \cup C} \times 100$ & $\begin{array}{c}\text { Percentage amount of } \\
\text { Intersection of Set } \mathrm{B} \text { to Set } \mathrm{C}\end{array}$ & $\begin{array}{c}\text { Amount of unity of a person's perception in } \\
\text { the second title state to first title state }\end{array}$ \\
\hline 10 & $\frac{B \Delta C}{B \cup C} \times 100$ & $\begin{array}{c}\text { Percentage amount of } \\
\text { changes of Set } \mathrm{C} \text { to Set } \mathrm{B}\end{array}$ & $\begin{array}{c}\text { Amount of changes of a person's perception } \\
\text { in the second title state to first title state }\end{array}$ \\
\hline
\end{tabular}

\section{CONCEPTS FOCUSED ON THE "TITLE"}

Although based on poststructuralist approaches in linguistics, a word phrase can have a large and varied implications, however, the implications will be stopped somewhere and/ or in other words do not enter some areas of the meanings (Safavi, 2004: 272). For example, the phrase "a glass of water" can imply concepts like ask a glass of water, the role of water on Earth's life, health, thirst and the like; and if this is considered as a metaphorical expression, we can extend the circle the implications to concepts like simplicity, honesty, pleasing, pureness and so on. So, if phrases and words appear in metaphorical combinations, its conceptual cycle that implies can be widely predicted. However, the scope of the implications will not cover all the concepts. In other words, some concepts can be considered focused on that phrase, some linked to it by metaphorical relationships and some very distant and impossible. Concepts focused on a phrase are more clearly implied by the phrase or words. These concepts do not include concepts obtained from a metaphoric phrase. According to this argument, the authors believe among 17 concepts referred by all members of the sample population for "Work 1" and among 13 concepts referred for "Work 2", concepts focused on each "title" can be obtained as given in "Table 4".

Table 4. Concepts focused on each title used in the test

\begin{tabular}{|c|c|c}
\hline \multirow{2}{*}{ No. } & Title & Concepts of each title \\
\hline \multirow{3}{*}{1} & "Love Elixir Fell on My Copper and ..." & - Romantic and mystical concepts \\
\cline { 2 - 3 } & "Nothingness" & $\begin{array}{c}\text { Despair and nothingness } \\
\text { - Opposed to nothingness }\end{array}$ \\
\hline \multirow{2}{*}{2} & "Modernity" & $\begin{array}{c}\text { - Concepts of novelty, change and to be } \\
\text { influenced } \\
\text { - Concepts of juxtaposition or contrast } \\
\text { between tradition and modernity }\end{array}$ \\
\cline { 2 - 3 } & "Looking for Authenticity Preservation" & $\begin{array}{c}\text { - Concepts about preserving the tradition } \\
\text { and present situations }\end{array}$ \\
\hline
\end{tabular}

"Table 4" states that, for example, when the "Work 1" as "Love Elixir Fell on My Copper and ..." is provided to the person, it is expected he has referred to "romantic and mystical concepts" in the questionnaire, of course if "title" has been able to affect his perception of the work.

\section{CALCULATING ABSOLUTE AND RELATIVE FREQUENCY OF THE GENERAL CODES}

"Table 5" that is drawn based on calculating the concepts' frequency of the perception of members of the sample population of "Work 1" shows that among all concepts, "Work 1" by itself and without a title, reflects the concepts of "despair and nothingness" more than other concepts, but no serious difference in relative frequency of concepts in this case states that the distribution of concepts is high in without title situation, and "Work 1" when released to the audience as without title, no clear orientation was found in the perception. Because the difference between the highest and lowest 
concept that has been mentioned in this case, is low and about 10 percent. But when the same work in the first title as "Love Elixir Fell on My Copper and ..." has been released to members of the sample population, the audience's perception of the work, became more toward "romantic and mystical concepts" and 53.5 percent of mentioned concepts have been drawn in that direction. Since "romantic and mystical concepts" are those focused on the concepts as "Love Elixir Fell on My Copper and ..." the authors predict the significant effect of the title on the audience's perception. "Table 5" also shows that after the second title, "Nothingness" on "Work 1", two concepts of "despair and nothingness" and "opposition to nothingness" have been in this case more than other concepts with relative frequency of 27.7 and 19.4 mentioned by the audience. Given that these two concepts are the concepts focused on "Nothingness", and have attracted a total of about 47 percent of the audience's perception, confirm the authors expectation of the occurrence of such an event. Last row of the "Table 5" represents a very important point that shows that by entitling "Work 1", it has been able to reduce the range of the concepts mentioned by the audience, from 58 to 28 and 36 of the absolute frequency.

Table 5. Concepts' frequency in without title and titled states in "Work 1"

\begin{tabular}{|c|c|c|c|c|c|c|c|}
\hline \multirow[b]{2}{*}{ Concepts } & \multicolumn{2}{|c|}{ Without title } & \multicolumn{2}{|c|}{$\begin{array}{l}\text { "Love Elixir Fell on } \\
\text { My Copper and ..." }\end{array}$} & \multicolumn{2}{|c|}{ "Nothingness" } & \multirow[b]{2}{*}{$\begin{array}{c}\text { Total } \\
\text { frequency }\end{array}$} \\
\hline & $\begin{array}{l}\text { Absolute } \\
\text { frequency }\end{array}$ & $\begin{array}{l}\text { relative } \\
\text { frequency }\end{array}$ & $\begin{array}{l}\text { Absolute } \\
\text { frequency }\end{array}$ & $\begin{array}{l}\text { relative } \\
\text { frequency }\end{array}$ & $\begin{array}{l}\text { Absolute } \\
\text { frequency }\end{array}$ & $\begin{array}{l}\text { relative } \\
\text { frequency }\end{array}$ & \\
\hline $\begin{array}{l}\text { Romantic and } \\
\text { mystical concepts }\end{array}$ & 6 & $10.34 \%$ & 15 & $53.57 \%$ & 6 & $16.66 \%$ & 27 \\
\hline $\begin{array}{l}\text { Despair and } \\
\text { nothingness }\end{array}$ & 8 & $13.79 \%$ & 2 & $7.14 \%$ & 10 & $27.77 \%$ & 20 \\
\hline The other & 4 & $6.89 \%$ & 3 & $10.71 \%$ & 2 & $5.55 \%$ & 9 \\
\hline $\begin{array}{l}\text { Creation and } \\
\text { destruction }\end{array}$ & 5 & $8.62 \%$ & 1 & $3.57 \%$ & 1 & $2.77 \%$ & 7 \\
\hline $\begin{array}{l}\text { Opposed to } \\
\text { nothingness }\end{array}$ & 0 & 0 & 0 & 0 & 7 & $19.44 \%$ & 7 \\
\hline $\begin{array}{l}\text { Concepts of } \\
\text { originality }\end{array}$ & 4 & $6.89 \%$ & 0 & 0 & 2 & $5.55 \%$ & 6 \\
\hline $\begin{array}{l}\text { Move and try in the } \\
\text { path of life and hope }\end{array}$ & 3 & $5.17 \%$ & 1 & $3.57 \%$ & 2 & $5.55 \%$ & 6 \\
\hline $\begin{array}{l}\text { Aging and the } \\
\text { passage of time }\end{array}$ & 5 & $8.62 \%$ & 0 & 0 & 1 & $2.77 \%$ & 6 \\
\hline Outburst and outflow & 5 & $8.62 \%$ & 0 & 0 & 0 & 0 & 5 \\
\hline $\begin{array}{l}\text { Induction of } \\
\text { confusion and } \\
\text { paradox }\end{array}$ & 3 & $5.17 \%$ & 1 & $3.57 \%$ & 1 & $2.77 \%$ & 5 \\
\hline Unity in diversity & 3 & $5.17 \%$ & 1 & $3.57 \%$ & 0 & 0 & 4 \\
\hline $\begin{array}{l}\text { Concepts of the } \\
\text { relationship between } \\
\text { redundancy and } \\
\text { essence }\end{array}$ & 2 & $3.44 \%$ & 1 & $3.57 \%$ & 1 & $2.77 \%$ & 4 \\
\hline
\end{tabular}


The Turkish Online Journal of Design, Art and Communication - TOJDAC January 2017 Volume 7 Issue 1

\begin{tabular}{|c|c|c|c|c|c|c|c|}
\hline $\begin{array}{c}\text { Induction of a } \\
\text { positive sense }\end{array}$ & 2 & $3.44 \%$ & 1 & $3.57 \%$ & 1 & $2.77 \%$ & 4 \\
\hline $\begin{array}{c}\text { Telling the story of } \\
\text { my life }\end{array}$ & 2 & $3.44 \%$ & 1 & $3.57 \%$ & 1 & $2.77 \%$ & 4 \\
\hline $\begin{array}{c}\text { Induction of negative } \\
\text { energy }\end{array}$ & 2 & $3.44 \%$ & 0 & 0 & 1 & $2.77 \%$ & 3 \\
\hline Brilliance & 3 & $5.17 \%$ & 0 & 0 & 0 & 0 & 3 \\
\hline $\begin{array}{c}\text { Spiritual presence } \\
\text { without a physical } \\
\text { presence }\end{array}$ & 1 & $1.72 \%$ & 1 & $3.57 \%$ & 0 & 0 & 2 \\
\hline Total & 58 & $100 \%$ & 28 & $100 \%$ & 36 & $100 \%$ & 122 \\
\hline
\end{tabular}

In accordance with what said about the frequency and distribution of concepts for "Work 1", "Table 6" shows the same things about "Work 2". "Table 6" shows that for without title "Work 2" respondents have referred to "contradiction and inconsistency" and "concepts of repairing" little more than the others, although relative frequency states no certain position on their behalf in this case. But once the work titled "Modernity" is provided to them, the perception is focused on the concepts related to this title suddenly, namely "concepts of novelty, change and to be influenced" and "concepts of preserving tradition and present situations" and when the work is provided with the title "Looking for Authenticity Preservation" at once the two codes are not considered and totally have attracted $15 \%$ "of the perception. This is while the code of "concepts of preserving tradition and present situations" (which is the concept focused on "Looking for Authenticity Preservation" as well) has attracted only $41 \%$ of the audience's perception in the second title. Last row of "Table 5 " also shows that the title of "Work 2" has been able to reduce the range of concepts mentioned by the audience as without title from 47 to 32 and 34 of the absolute frequency.

Table 6. Concepts' frequency in without title and titled states of "Work 2"

\begin{tabular}{|c|c|c|c|c|c|c|c|}
\hline \multirow[b]{2}{*}{ Concepts } & \multicolumn{2}{|c|}{ Without title } & \multicolumn{2}{|c|}{ "Modernity" } & \multicolumn{2}{|c|}{$\begin{array}{l}\text { "Looking for } \\
\text { Authenticity } \\
\text { Preservation" }\end{array}$} & \multirow[b]{2}{*}{$\begin{array}{c}\text { Total } \\
\text { frequency }\end{array}$} \\
\hline & $\begin{array}{l}\text { Absolute } \\
\text { frequency }\end{array}$ & $\begin{array}{c}\text { relative } \\
\text { frequency }\end{array}$ & $\begin{array}{l}\text { Absolute } \\
\text { frequency }\end{array}$ & $\begin{array}{l}\text { relative } \\
\text { frequency }\end{array}$ & $\begin{array}{l}\text { Absolute } \\
\text { frequency }\end{array}$ & $\begin{array}{l}\text { relative } \\
\text { frequency }\end{array}$ & \\
\hline $\begin{array}{c}\text { Concepts of preserving } \\
\text { tradition and present } \\
\text { situations } \\
\end{array}$ & 4 & $8.51 \%$ & 3 & $9.37 \%$ & 14 & $41.17 \%$ & 21 \\
\hline $\begin{array}{l}\text { Concepts of novelty, } \\
\text { change and to be } \\
\text { influenced }\end{array}$ & 4 & $8.51 \%$ & 10 & $31.25 \%$ & 4 & $11.76 \%$ & 18 \\
\hline $\begin{array}{c}\text { Contradiction and } \\
\text { inconsistency }\end{array}$ & 9 & $19.14 \%$ & 4 & $12.5 \%$ & 3 & $8.82 \%$ & 16 \\
\hline Concepts of repairing & 9 & $19.14 \%$ & 1 & $3.12 \%$ & 3 & $8.82 \%$ & 13 \\
\hline $\begin{array}{c}\text { Concepts of } \\
\text { juxtaposition or }\end{array}$ & 3 & $6.38 \%$ & 6 & $18.75 \%$ & 1 & $2.94 \%$ & 10 \\
\hline
\end{tabular}




\begin{tabular}{|c|c|c|c|c|c|c|c}
\hline $\begin{array}{c}\text { contrast between } \\
\text { tradition and } \\
\text { modernity }\end{array}$ & 2 & $4.25 \%$ & 4 & $12.5 \%$ & 4 & $11.76 \%$ & 10 \\
\hline $\begin{array}{c}\text { The other } \\
\begin{array}{c}\text { An attempt to prolong } \\
\text { life }\end{array}\end{array}$ & 4 & $8.51 \%$ & 3 & $9.37 \%$ & 1 & $2.94 \%$ & 8 \\
\hline $\begin{array}{c}\text { Nostalgia and good } \\
\text { sense }\end{array}$ & 5 & $10.63 \%$ & 0 & 0 & 1 & $2.94 \%$ & 6 \\
\hline Recalling nature & 3 & $6.38 \%$ & 0 & 0 & 1 & $2.94 \%$ & 4 \\
\hline Weakness & 1 & $2.12 \%$ & 0 & 0 & 1 & $2.94 \%$ & 2 \\
\hline $\begin{array}{c}\text { Regarding the } \\
\text { judgment of others } \\
\text { about yourself }\end{array}$ & 0 & 0 & 1 & $3.12 \%$ & 1 & $2.94 \%$ & 2 \\
\hline Materialistic pacifism & 2 & $4.25 \%$ & 0 & 0 & 0 & 0 & 2 \\
\hline $\begin{array}{c}\text { concepts of inner and } \\
\text { outer beauty }\end{array}$ & 1 & $2.12 \%$ & 0 & 0 & 0 & 0 & 1 \\
\hline Total & 47 & $100 \%$ & 32 & $100 \%$ & 34 & $100 \%$ & 113 \\
\hline
\end{tabular}

THE EFFECT OF TITLE ON THE CENTRALIZATION OF AUDIENCE'S PERCEPTION TO CONCEPTS FOCUSED ON THE TITLE

The authors have drawn "Table 7" to investigate the effect of each title on the centralization of the audience's perception to the concepts focused, in each of these two conceptual works. This Table is based on counting the number of concepts which have been mentioned by any sample members in any of the titled states and the number of concepts focused on each of those titles in the same state. According to "Table 7", the title "Love Elixir Fell on My Copper and ..." on average has attracted $68.5 \%$ of the audience's perception and moved it toward its concepts.

It is very important that the effect on 7 persons was 100 percent. The title "Nothingness" has been also able to attract an average of about 59 percent of the perception of members of the sample population to the concepts focused on the "title"; as well as among 15 members of the sample population it has been effective on 5 people 100 percent. Another important point to note is that although the first title (Love Elixir Fell on My Copper and ...) has a greater metaphorical effect than the second title (Nothingness) it is expected that due to a wider range of implications of a metaphorical expression, the effect of centralizing the title on the audience's perception is less, but "Table 7" shows that, contrary to what is expected, the second title ("Nothingness" that consists only of one word) has been effective about $10 \%$ lower than the first title on focusing mind of the audience and has been less successful on convergent audience's perception of the work. One of the reasons can be an intertextual relationship between the title "Love Elixir Fell on My Copper and ..." and a famous couplet of Saadi Shirazi ${ }^{(2)}$ that causes recalling the full content of this poem and associations related to it in the mind and the same perception of "Work 1" in this case.

According to "Table 7", in "Work 2", "Modernity" on average has attracted about 53 percent of the audience's perception to its concepts. The title was ineffective on two members of the sample population, but as on 3 members has been 100 percent. "Looking for Authenticity Preservation" on average has controlled less than half of the audience's perception (about 47 percent) to its concepts. 
The Turkish Online Journal of Design, Art and Communication - TOJDAC January 2017 Volume 7 Issue 1

Table 7. Comparison of the percentage effect of the first and second titles* on the audience's perception of "Works 1 and 2" toward the concepts focused on the title

\begin{tabular}{|c|c|c|c|c|}
\hline \multirow[b]{2}{*}{$\begin{array}{l}\text { D } \\
0 \\
0 \\
0 \\
0 \\
0 \\
0 \\
0 \\
0 \\
0 \\
0 \\
0 \\
0\end{array}$} & \multicolumn{2}{|c|}{ "Work 1" } & \multicolumn{2}{|c|}{ "Work 2" } \\
\hline & $\begin{array}{l}\text { percentage effect of } \\
\text { the first title on } \\
\text { audience's } \\
\text { perception of the } \\
\text { work into the } \\
\text { concepts focused } \\
\text { on the first title }\end{array}$ & $\begin{array}{l}\text { percentage effect of } \\
\text { the second title on } \\
\text { audience's } \\
\text { perception of the } \\
\text { work into the } \\
\text { concepts focused } \\
\text { on the second title }\end{array}$ & $\begin{array}{l}\text { percentage effect of } \\
\text { the first title on } \\
\text { audience's perception } \\
\text { of the work into the } \\
\text { concepts focused on } \\
\text { the first title }\end{array}$ & $\begin{array}{l}\text { percentage effect of } \\
\text { the second title on } \\
\text { audience's } \\
\text { perception of the } \\
\text { work into the } \\
\text { concepts focused } \\
\text { on the second title }\end{array}$ \\
\hline 01 & $50 \%$ & $50 \%$ & $50 \%$ & $50 \%$ \\
\hline 02 & $25 \%$ & $50 \%$ & $50 \%$ & $25 \%$ \\
\hline 03 & $50 \%$ & $25 \%$ & 0 & $50 \%$ \\
\hline 04 & $20 \%$ & $28.57 \%$ & $100 \%$ & $33.33 \%$ \\
\hline 05 & $33.33 \%$ & $66.66 \%$ & $50 \%$ & $50 \%$ \\
\hline 06 & $50 \%$ & $33.33 \%$ & $50 \%$ & $50 \%$ \\
\hline 07 & $50 \%$ & $50 \%$ & $100 \%$ & $50 \%$ \\
\hline 08 & $100 \%$ & 0 & $50 \%$ & $50 \%$ \\
\hline 09 & $100 \%$ & $100 \%$ & $50 \%$ & $50 \%$ \\
\hline 10 & $100 \%$ & $50 \%$ & $66.66 \%$ & 0 \\
\hline 11 & $100 \%$ & $100 \%$ & $50 \%$ & $50 \%$ \\
\hline 12 & $100 \%$ & $100 \%$ & 0 & $50 \%$ \\
\hline 13 & $50 \%$ & $100 \%$ & $33.33 \%$ & $50 \%$ \\
\hline 14 & $100 \%$ & $33.33 \%$ & $100 \%$ & $50 \%$ \\
\hline 15 & $100 \%$ & $100 \%$ & $50 \%$ & $100 \%$ \\
\hline $\begin{array}{c}\text { Averag } \\
\text { e }\end{array}$ & $68.55 \%$ & $59.12 \%$ & $53.33 \%$ & $47.22 \%$ \\
\hline $\begin{array}{c}\text { Averag } \\
\text { e of } \\
\text { both } \\
\text { states } \\
\end{array}$ & \multicolumn{2}{|c|}{$63.81 \%$} & \multicolumn{2}{|c|}{$50.27 \%$} \\
\hline
\end{tabular}

*: The first and second titles of "Work 1" are "Love Elixir Fell on My Copper And..." and "Modernity", respectively and the first and second titles of "Work 2" are "Modernity" and "Looking for Authenticity Preservation", respectively.

With comparison of average amount of the titles directing on the audience's perception in the last row of "Table 7", it appears that the titles on average in "Work 1" in comparison with ones in "Work 2" have had a greater effect on the audience's perception in directing towards the concepts focused on the title, and about 13.5 percent have been more effective. The main reason for this can be found in the nature of "Work 1". In other words, since "Work 1" has less forms than "Work 2", it is obviouse that its circle of implications would be wider than "Work 2". Thus, in "Work 1 " there is a better platform to lead the audience to its intended direction.

\section{THE EFFECT OF TITLE ON AMOUNT OF LIMITATION, EXPANSION AND CHANGES OF THE AUDIENCE'S PERCEPTION}

In this section, the title function based on Set Theory and "formula 1-10" (in Table 3), 4 characteristics of the audience's perception can be calculated for each member of the sample population:

- The amount of limitation of the audience's perception due to "title" to without title state

- The amount of expansion of the audience's perception due to "title" to without title state

- The amount of unity of the audience's perception among without title and titled states

- The amount of changes of the audience's perception due to the title to the previous state 
Accordingly, "Tables 8 and 9" have been calculated and plotted to consider above four characteristics in each sample members' perception in various states. "Table 8 " shows that, on average, by titling "Work 1" with "Love Elixir Fell on My Copper and ..." it has been able to limit the audience's perception about 60 percent to without title state which seen by the audience. This means that the range of concepts that the work has implied them has been reduced by "title" then extended $19 \%$ and new concepts have been born. $20.5 \%$ of concepts still have remained common and well. By titling "Work 1" totally, respondents' perception of this work has changed about $79.5 \%$ in comparison with without title state.

This high rate of change is very important. Because, only with the advent of some words, the meaning of the work has significantly changed. "Table 8 " also investigates the effect of the second title to without title of "Work 1" and the results. In the last two columns (from right) of the Table, the second title effect on the audience has been evaluated to the effect of the first title, and in this comparison, characteristics of "limitation" and "expansion" of the audience's perception would not be significant, because the first title cannot be considered as the basis to study the second title effect whereby to investigate the amount of "limitation" or "expansion" of a person perception. Thus, the amount of "unity" and "changes" of the perception of members of the sample population is calculated in two states and provided in these two columns.

Table 8. The amount of limitation, expansion, unity and changes of the audience's perception of "Work 1" in titled states* to without title state and the previous state

\begin{tabular}{|c|c|c|c|c|c|c|c|c|c|c|}
\hline \multirow[b]{2}{*}{$\begin{array}{l}20 \\
0 \\
0 \\
0 \\
0 \\
0 \\
0 \\
0 \\
0 \\
8 \\
0 \\
0\end{array}$} & \multicolumn{4}{|c|}{$\begin{array}{l}\text { Audience's perception in first titled } \\
\text { to without title state }\end{array}$} & \multicolumn{4}{|c|}{$\begin{array}{l}\text { Audience's perception in second } \\
\text { titled to without title state }\end{array}$} & \multicolumn{2}{|c|}{$\begin{array}{c}\text { Audience's } \\
\text { perception in } \\
\text { second titled to } \\
\text { first titled state }\end{array}$} \\
\hline & 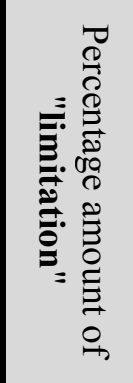 & 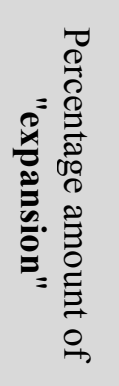 & 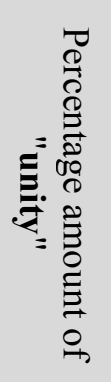 & 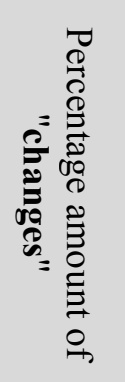 & 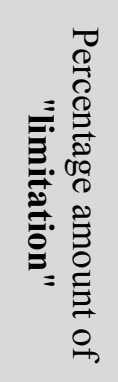 & 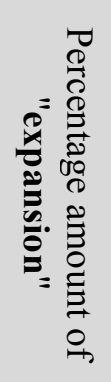 & 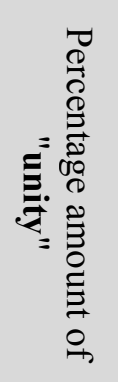 & 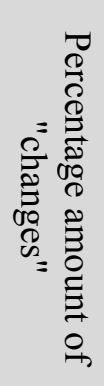 & 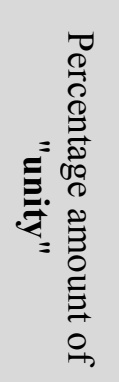 & 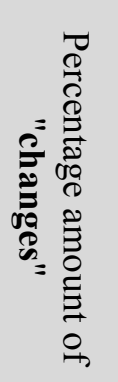 \\
\hline 01 & 71.42 & 14.28 & 14.28 & 85.71 & 66.66 & 0 & 33.33 & $\begin{array}{c}66.6 \\
6\end{array}$ & 33.33 & 66.66 \\
\hline 02 & 33.33 & 16.66 & 50 & 50 & 42.85 & 28.57 & 28.57 & $\begin{array}{c}71.4 \\
2\end{array}$ & 33.33 & 66.66 \\
\hline 03 & 50 & 0 & 50 & 50 & 33.33 & 33.33 & 33.33 & $\begin{array}{c}66.6 \\
6\end{array}$ & 50 & 50 \\
\hline 04 & 37.5 & 37.5 & 25 & 75 & 30 & 50 & 20 & 80 & 33.33 & 66.66 \\
\hline 05 & 57.14 & 14.28 & 28.57 & 71.42 & 57.14 & 14.28 & 28.57 & $\begin{array}{c}71.4 \\
2\end{array}$ & 0 & 100 \\
\hline 06 & 57.14 & 14.28 & 28.57 & 71.42 & 57.14 & 28.57 & 14.28 & $\begin{array}{c}85.7 \\
1\end{array}$ & 25 & 75 \\
\hline 07 & 60 & 20 & 20 & 80 & 66.66 & 33.33 & 0 & 100 & 25 & 75 \\
\hline 08 & 50 & 0 & 50 & 50 & 50 & 0 & 50 & 50 & 100 & 0 \\
\hline 09 & 75 & 0 & 25 & 75 & 80 & 20 & 0 & 100 & 0 & 100 \\
\hline 10 & 80 & 20 & 0 & 100 & 60 & 20 & 20 & 80 & 0 & 100 \\
\hline
\end{tabular}


The Turkish Online Journal of Design, Art and Communication - TOJDAC January 2017 Volume 7 Issue 1

\begin{tabular}{|c|c|c|c|c|c|c|c|c|c|c}
\hline 11 & 50 & 50 & 0 & 100 & 50 & 50 & 0 & 100 & 0 & 100 \\
\hline 12 & 66.66 & 33.33 & 0 & 100 & 66.66 & 33.33 & 0 & 100 & 0 & 100 \\
\hline 13 & 66.66 & 16.66 & 16.66 & 83.33 & 80 & 0 & 20 & 80 & 0 & 100 \\
\hline 14 & 75 & 25 & 0 & 100 & 40 & 40 & 20 & 80 & 0 & 100 \\
\hline 15 & 75 & 25 & 0 & 100 & 66.66 & 0 & 33.33 & $\begin{array}{c}66.6 \\
6\end{array}$ & 0 & 100 \\
\hline $\begin{array}{c}\text { Averag } \\
\text { e }\end{array}$ & 60.32 & 19.13 & 20.53 & 79.45 & 56.47 & 23.42 & 20.09 & 79.9 & 19.99 & 79.99 \\
\hline
\end{tabular}

*: Titled states of "Work 1" include the first titled state ("Love Elixir Fell on My Copper And...") and the second titled state ("Nothingness").

Like what has been explained for the effect of the title on the audience in the case of "Work 1" in "Table 8", also "Table 9" has provided the results of study and calculate the effect of the "title" on respondents' perception in the case of "Work 2".

Table 9. The amount of limitation, expansion, unity and changes of the audience's perception of titled states* to without title and the previous state of "Work 2"

\begin{tabular}{|c|c|c|c|c|c|c|c|c|c|c|}
\hline \multirow[b]{2}{*}{$\begin{array}{l}7 \\
0 \\
0 \\
0 \\
0 \\
0 \\
0 \\
0 \\
0 \\
0 \\
0 \\
8 \\
0 \\
0 \\
0\end{array}$} & \multicolumn{4}{|c|}{$\begin{array}{l}\text { Audience's perception in first titled } \\
\text { to without title state }\end{array}$} & \multicolumn{4}{|c|}{$\begin{array}{l}\text { Audience's perception in second } \\
\text { titled to without title state }\end{array}$} & \multicolumn{2}{|c|}{$\begin{array}{l}\text { Audience's } \\
\text { perception in } \\
\text { second titled to } \\
\text { first titled state }\end{array}$} \\
\hline & 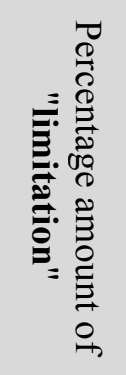 & 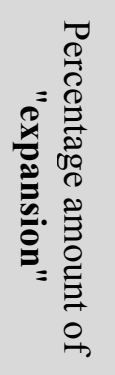 & 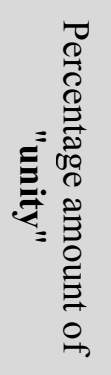 & 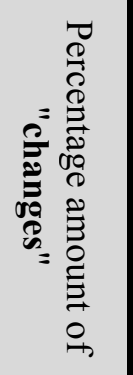 & 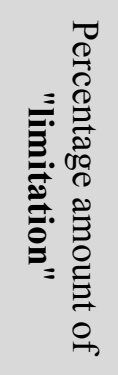 & 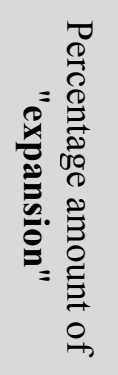 & 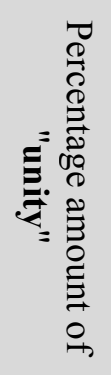 & 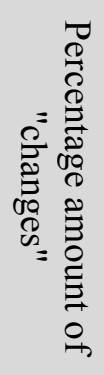 & 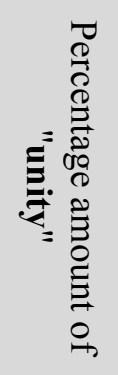 & 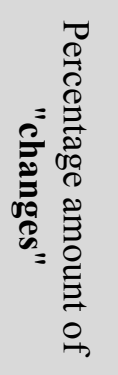 \\
\hline 01 & 66.66 & 33.33 & 0 & 100 & 50 & 0 & 50 & 50 & 0 & 100 \\
\hline 02 & 33.33 & 50 & 16.66 & 83.33 & 33.33 & 50 & 16.66 & $\begin{array}{c}83.3 \\
3 \\
\end{array}$ & 60 & 40 \\
\hline 03 & 60 & 40 & 0 & 100 & 50 & 25 & 25 & 75 & 33.33 & 66.66 \\
\hline 04 & 66.66 & 16.66 & 16.66 & 83.33 & 50 & 16.66 & 33.33 & $\begin{array}{c}66.6 \\
6\end{array}$ & 0 & 100 \\
\hline 05 & 60 & 20 & 20 & 80 & 66.66 & 33.33 & 0 & 100 & 33.33 & 66.66 \\
\hline 06 & 50 & 25 & 25 & 75 & 60 & 40 & 0 & 100 & 0 & 100 \\
\hline 07 & 66.66 & 33.33 & 0 & 100 & 33.33 & 33.33 & 33.33 & $\begin{array}{c}66.6 \\
6 \\
\end{array}$ & 0 & 100 \\
\hline 08 & 0 & 50 & 50 & 50 & 0 & 50 & 50 & 50 & 33.33 & 66.66 \\
\hline 09 & 50 & 25 & 25 & 75 & 50 & 25 & 25 & 75 & 100 & 0 \\
\hline 10 & 57.14 & 14.28 & 28.57 & 71.42 & 42.85 & 14.28 & 42.85 & $\begin{array}{c}57.1 \\
4\end{array}$ & 40 & 60 \\
\hline 11 & 33.33 & 66.66 & 0 & 100 & 33.33 & 66.66 & 0 & 100 & 100 & 0 \\
\hline
\end{tabular}


The Turkish Online Journal of Design, Art and Communication - TOJDAC January 2017 Volume 7 Issue 1

\begin{tabular}{|c|c|c|c|c|c|c|c|c|c|c}
\hline 12 & 33.33 & 0 & 66.66 & 33.33 & 50 & 25 & 25 & 75 & 33.33 & 66.66 \\
\hline 13 & 50 & 33.33 & 16.66 & 83.33 & 60 & 20 & 20 & 80 & 25 & 75 \\
\hline 14 & 75 & 0 & 25 & 75 & 66.66 & 33.33 & 0 & 100 & 0 & 100 \\
\hline 15 & 50 & 50 & 0 & 100 & 66.66 & 33.33 & 0 & 100 & 0 & 100 \\
\hline $\begin{array}{c}\text { Averag } \\
\text { e }\end{array}$ & 50.14 & 30.5 & 19.34 & 80.64 & 47.52 & 31.06 & 21.41 & $\begin{array}{c}78.5 \\
8\end{array}$ & 30.55 & 69.44 \\
\hline
\end{tabular}

*: Titled states of "Work 2" include the first titled state ("Modernity") and the second titled state ("Looking for Authenticity Preservation").

\section{THE "CONCEPT" TURNING}

The titles which have been used in this study at titled states have been selected in a way that their meaning would be almost in contradiction or conflict with each other and each title orientation is in opposite of the other, so that one is in positive direction and the other in negative direction in order to study the "concept turning" because of "the title effect". Thus, the titles used for "Work 1" are "Love Elixir Fell on My Copper and ..." and "Nothingness" that the first title is further toward romantic and mystical topics opposite of nothingness topics as implied by the second title. This trend has been also applied in the titles used to "Work 2" and titles accordingly have been selected as "Modernity" and "Looking for Authenticity Preservation". So, "the concept turning" means a significant shift in the audience's perception from the first title concepts toward concepts of the second title. For example, if respondents after facing with the first title refer to the first title concepts in their perception and after facing with the second title refer to the second title concepts without referring to the first title concepts, "title" has been able to turn the concept of artwork and "the concept turning" fully occurred. "the concept turning" is a continuous quantity, and their values can be calculated. "Table 10" shows how and to what extent in "Works 1 and 2 " have been able to turn the perception of respondents.

Table 10. The amount of concept "turning" of "Works 1 and 2 " due to the first and second titles*

\begin{tabular}{|c|c|c|c|c|c|c|}
\hline \multirow[b]{2}{*}{$\begin{array}{l}2 \\
0 \\
0 \\
0 \\
0 \\
0 \\
0 \\
0 \\
0 \\
0 \\
8 \\
0 \\
0\end{array}$} & \multicolumn{3}{|c|}{ "Work 1" } & \multicolumn{3}{|c|}{ "Work 2" } \\
\hline & $\begin{array}{c}\text { Effect } \\
\text { Percentage } \\
\text { amount of the } \\
\text { first title on } \\
\text { audience's } \\
\text { perception of } \\
\text { the work to the } \\
\text { concepts } \\
\text { focused on the } \\
\text { title }\end{array}$ & $\begin{array}{c}\text { Effect } \\
\text { Percentage } \\
\text { amount of the } \\
\text { second title } \\
\text { on audience's } \\
\text { perception of } \\
\text { the work to } \\
\text { the concepts } \\
\text { focused on } \\
\text { the title }\end{array}$ & $\begin{array}{l}\text { Percentage } \\
\text { amount of } \\
\text { concept } \\
\text { "turning" }\end{array}$ & $\begin{array}{l}\text { Effect Percentage } \\
\text { amount of the } \\
\text { first title on } \\
\text { audience's } \\
\text { perception of the } \\
\text { work to the } \\
\text { concepts focused } \\
\text { on the title }\end{array}$ & $\begin{array}{c}\text { Effect } \\
\text { Percentage } \\
\text { amount of the } \\
\text { second title on } \\
\text { audience's } \\
\text { perception of } \\
\text { the work to } \\
\text { the concepts } \\
\text { focused on the } \\
\text { title }\end{array}$ & $\begin{array}{l}\text { Percentage } \\
\text { amount of } \\
\text { concept } \\
\text { "turning" }\end{array}$ \\
\hline 01 & $50 \%$ & $50 \%$ & $50 \%$ & $50 \%$ & $50 \%$ & $50 \%$ \\
\hline 02 & $25 \%$ & $50 \%$ & $37.5 \%$ & $50 \%$ & $25 \%$ & $37.5 \%$ \\
\hline 03 & $50 \%$ & $25 \%$ & $37.5 \%$ & 0 & $50 \%$ & $25 \%$ \\
\hline 04 & $20 \%$ & $28.57 \%$ & $24.29 \%$ & $100 \%$ & $33.33 \%$ & $66.66 \%$ \\
\hline 05 & $33.33 \%$ & $66.66 \%$ & $49.99 \%$ & $50 \%$ & $50 \%$ & $50 \%$ \\
\hline 06 & $50 \%$ & $33.33 \%$ & $41.66 \%$ & $50 \%$ & $50 \%$ & $50 \%$ \\
\hline 07 & $50 \%$ & $50 \%$ & $50 \%$ & $100 \%$ & $50 \%$ & $75 \%$ \\
\hline 08 & $100 \%$ & 0 & $50 \%$ & $50 \%$ & $50 \%$ & $50 \%$ \\
\hline 09 & $100 \%$ & $100 \%$ & $100 \%$ & $50 \%$ & $50 \%$ & $50 \%$ \\
\hline
\end{tabular}


The Turkish Online Journal of Design, Art and Communication - TOJDAC January 2017 Volume 7 Issue 1

\begin{tabular}{|c|c|c|c|c|c|c}
\hline 10 & $100 \%$ & $50 \%$ & $75 \%$ & $66.66 \%$ & 0 & $33.33 \%$ \\
\hline 11 & $100 \%$ & $100 \%$ & $100 \%$ & $50 \%$ & $50 \%$ & $50 \%$ \\
\hline 12 & $100 \%$ & $100 \%$ & $100 \%$ & 0 & $50 \%$ & $25 \%$ \\
\hline 13 & $50 \%$ & $100 \%$ & $75 \%$ & $33.33 \%$ & $50 \%$ & $41.66 \%$ \\
\hline 14 & $100 \%$ & $33.33 \%$ & $66.66 \%$ & $100 \%$ & $50 \%$ & $75 \%$ \\
\hline 15 & $100 \%$ & $100 \%$ & $100 \%$ & $50 \%$ & $100 \%$ & $75 \%$ \\
\hline Average & $68.55 \%$ & $59.12 \%$ & $63.83 \%$ & $53.33 \%$ & $47.22 \%$ & $50.27 \%$ \\
\hline
\end{tabular}

*: The first and second titles of "Work 1" are "Love Elixir Fell on My Copper And..." and "Modernity", respectively and the first and second titles of "Work 2" are "Modernity" and "Looking for Authenticity Preservation", respectively.

\section{RESULTS}

The study results show that the title is effective on transferring the concepts of conceptual visual art works and can change concepts $70-80 \%$, and turn $50-64 \%$ to concepts implied, but cannot thin it out into one. "Title" is also able to limit audience's perception of these works $47-61 \%$ and expand it 19 $32 \%$ and create new concepts.

According to the results of previous studies on the effect of "title" on the audience's perception of an art work that show "title" affects the audience's perception (Abdollahabadi and Moghimnezhad, 2012 and Moadikhah and Namvar Motlaq, 2013 and Franklin et al., 1993 and Ledera et al., 2006), in conceptual art that audience's perception of the work is highly regarded, the "title" role is a serious matter. A conceptual artist by entitling his work makes a language game on the concept between the "title" and "what is screened", furthermore forms the final concept of the artwork. Although with the acceptance of Modern Hermeneutics in contemporary art, the role of author in reading the work is fading down to zero, but it can be said that in conceptual visual artworks, "title" can change the author's role from zero (as a alone creator) and turn it into an effective role. The results of the present study also prove the claim, as if "Work 1" with the first title (Love Elixir Fell on My Copper and ...) was introduced to the audience, $68.5 \%$ of the audience's perception directed to the concepts focused by the first title and when the second title was introduced (Nothingness) to them, $59.12 \%$ of the audience's perception directed to concepts focused by the second title too, and other readings were limited. This was true for "Work 2" and the direction amounts of audience's perception toward the concepts focused by titles respectively, were 53.33 and 47.22 percent. Thus, the work creator by titling his work paves the way for reading of the audience and conducts him to the specific directions.

Given that the phenomenon investigated in this study is the audience's perception of a work of art, many factors other than the independent variable (title) affect it that should be considered as the most important limitation of this research. For example, the researcher cannot clear personal experience of the members of the sample population in their minds and control associations recalled by each art work in the audience's mind (originated in their personal life). So, although the researchers first have conducted a pre-test (without title state), but not all changes resulting from the post-test (titled states) will be considered born of the effect of the independent variable.

According to the results of semi-experimental and quantitative stages of this research, the authors suggest that future researchers examine the "title" function in other conceptual arts, especially musical and installation works quantitatively and qualitatively in order to besides the results of this study, a decisive opinion can be obtained on the role of "title" in all works of conceptual art.

\section{SUBSCRIPTS}

1. This title is a part of Saadi Shirazi's famous poem that says: “"Who made your red face golden? Saadi" They asked. Love elixir fell on my copper and I got gold". According to a 
historic mystical Persian opinion, love can change someone into Perfect Man as the alchemy can make change copper into gold.

2. Saadi Shirazi. 1210-1291. He was one of the major Persian poets and literary men of the medieval period.

\section{REFERENCES}

Osborne, Peter (2012). Conceptual Art, translation: Rohani, N., Markab-e-Sefid Publication, Tehran. Stewart, Ian and Tull, David (1986). Foundations of Mathematics, translation: Dr. Mehdi Ebrahimi, Tehran University Press.

Jamal, A. (2004). General Topology, Payam Noor University Press, Tehran.

Safavi, K. (2004), Introduction to Semantics, Sora Publication, Tehran.

Abdollahabadi, E., and Moghimnejad, M. (2012). A Study of Title Role in Expressive Functions of photos (The Title in Photographs of Contemporary Iranian Art), master thesis, School of Visual Arts, Art University of Tehran.

Creswell, John W. (2013). Qualitative, Quantitative and Sequential Approaches' Research Design, translation: Alireza Kiamanesh and Maryam Dana Tus, Jihad Publications, Allameh Tabatabai branch, Tehran.

Luci-Smith, Edward (2008). Concepts and Approaches in the Latest Art Movements of the Twentieth Century, translation: Alireza Samiazar, Nazar Publication, Tehran.

Moadikhah, S. and Namvar Motlaq, B. (2013). Title Paratextualite and Titling as a Threshold of Text in Cinema with an Emphasis on Abbas Kiarostami's films, master thesis, Isfahan University of Arts.

Franklin, Margery B., Becklen, Robert C. and Doyle, Charlotte L. (1993), The Influence of Titles on How Paintings Are Seen, Leonardo, The MIT Press, 26, 2, 103-108

Ledera, H. Carbona, C. and Ripsasb, A. (2006), Entitling Art: Influence of Title Information on Understanding and Appreciation of Paintings, Acta Psychologica, 121, 2, 176-198 